\title{
Aedes (Ochlerotatus) lepidus (Cerqueira \& Paraense, 1945): new record from Mato Grosso do Sul state, Brazil
}

\author{
Paulo Silva de Almeida ${ }^{1 *}$, Rosilene Francisca Moreira ${ }^{1}$, José Oliveira da Silva ${ }^{1}$, Talita Moreira \\ Silva $^{1}$, Pedro Catarino da Costa Filho ${ }^{2}$, Claucio Junior De Souza Carrijo ${ }^{2}$, Herintha Coeto \\ Neitzke-Abreu ${ }^{3}$, Marcos Takashi Obara ${ }^{4}$, Andreia Fernandes Brilhante ${ }^{5}$, Marcia Bicudo de Paula ${ }^{6}$, \\ Ricardo Augusto dos Passos ${ }^{7}$
}

1 Secretaria de Saúde do Estado de Mato Grosso do Sul, Laboratório Regional de Entomologia, Dourados, MS, Brazil •PSA: psilvadealmeida@ yahoo.com.br (1) https://orcid.org/0000-0003-2248-8142 • RFM: rosilenefranciscamoreira@hotmail.com (D https://orcid.org/0000-0002-14635694•JOS: joslive2006@yahoo.com.br (1) https://orcid.org/0000-0002-2682-2999•TMS: talitamoreira-silva@hotmail.com (D https://orcid. org/0000-0003-0506-8410

2 Prefeitura Municipal de Alcinópolis, Alcinópolis, MS, Brazil • PCCF: catarinocosta@hotmail.com @ https://orcid.org/0000-0001-6729-5753 • CJSC: clauciojrcarrijo36@gmail.com (1) https://orcid.org/0000-0001-8754-6185

3 Universidade Federal da Grande Dourados, Programa de Pós-Graduação em Ciências da Saúde, Dourados, MS, Brazil • herinthaabreu@ufgd. edu.br (D https://orcid.org/0000-0001-5848-670X

4 Universidade de Brasília, Laboratório de Parasitologia Médica e Biologia de Vetores, Brasília, DF, Brazil • marcos.obara@gmail.com (Dhttps:// orcid.org/0000-0001-6872-0096

5 Universidade Federal do Acre, Centro de Ciências de Saúde e do Desporto, Rio Branco, AC, Brazil • andreia.brilhante@ufac.br@ @ttps://orcid. org/0000-0002-4436-432X

6 Universidade de São Paulo, Faculdade de Saúde Pública, Pacaembu, SP, Brazil • bicudo@usp.br @ https://orcid.org/0000-0001-5958-8601

7 Universidade Federal da Grande Dourados, Faculdade de Ciências Biológicas e Ambientais, Dourados, MS, Brazil•ricdospassos@gmail.com (D) https://orcid.org/0000-0002-2155-9351

* Corresponding author

\begin{abstract}
Aedes (Ochlerotatus) lepidus (Cerqueira \& Paraense, 1945) is reported from a cave in Templo dos Pilares Municipal Park, Mato Grosso do Sul state, Brazil. A single exploratory collection of culicids was carried out using CDC light traps on 16 November 2015. Four larvae and 11 adults $\left(1 \delta^{\lambda}, 10\right.$ \% $)$ were collected. The larvae were found in a waterfilled hole in a stone. This is the first record of the species in Mato Grosso do Sul, which increases to 63 the number of culicids species recorded in the state.
\end{abstract}

Keywords

Culicids, geographical distribution, entomology, geographic range extension

Academic editor: Fabio Laurindo da Silva | Received 17 March 2021 | Accepted 17 May 2021 | Published 28 May 2021

Citation: Almeida PS, Moreira RF, Silva JO, Silva TM, Filho PCC, Carrijo CJS, Neitzke-Abreu HC, Obara MT, Brilhante AF, Paula, Passos MBR (2021) Aedes (Ochlerotatus) lepidus (Cerqueira \& Paraense, 1945): new record from Mato Grosso do Sul state, Brazil. Check List 17 (2): $821-825$. https://doi.org/10.15560/17.3.821 


\section{Introduction}

Mosquitoes of the family Culicidae are important in the public health, as they are involved in the transmission of multiple infectious agents to humans and animals (Gaffigan et al. 2015). In the subfamily Culicinae, the tribes Aedini and Culicini include several species of epidemiological interest. The Aedini have a wide geographical distribution (Harbach 2021a) and the tribe includes 10 genera, among which Aedes, Haemagogus, and Psorophora are Neotropical representatives that occur in Brazil (Wilkerson et al. 2015).

The genus Aedes comprises approximately 935 species in 78 subgenera (Wilkerson et al. 2015). According to Hutchings et al. (2020), Aedes comprises 32 species in five subgenera. Aedes (Stegomyia) aegypti (Linnaeus in Hasselquist, 1762) and Aedes (Ste.) albopictus (Skuse, 1894) were introduced in Brazil and have high epidemiological importance for being as primary or secondary vectors in the transmission of arboviruses (Consôli and Lourenço-de-Oliveira 1994; Martins et al. 2013). Aedes lepidus is still poorly understood, and its distribution seems to be restricted to the states of Mato Grosso and Minas Gerais as well as northeastern Brazil (Cerqueira 1957; Paraense 1945; Xavier et al. 1980; Andrade et al. 2020). We report the first occurrence of Aedes (Ochlerotatus) lepidus (Cerqueira \& Paraense, 1945) in Mato Grosso do Sul state, collected from a caveat Templo dos Pilares Municipal Natural Park.

\section{Methods}

The state of Mato Grosso do Sul has numerous archaeological sites with rock art, of which one-third are in the municipality of Alcinópolis. The municipality also has the most emblematic archaeological site of rock art in the region, known as Templo dos Pilares (Aguiar et al. 2016).

Templo dos Pilares Municipal Park has traces of ancient inhabitants dating back to 11,000 years before present. The park has engravings and paintings on walls and ceilings, and curious rock formations in the shape of pilars. The park is part of the Emas Corridor/Taquari Conservation Unit and is located in a transition area between the Cerrado and Pantanal biomes. The area has high touristic use due to the panoramic views, natural landscapes, and rare plants (Prefeitura de Alcinópolis 2019).

During a survey about phlebotomine sandflies (Almeida et al. 2019), a single exploratory collection was made at Templo dos Pilares (Fig. 1) using CDC light traps for 12 consecutive hours $(6: 00 \mathrm{pm}$ to $6: 00 \mathrm{am})$ on 16 November 2015 . When the research team was exploring the site, a water-filled hole in a stone was found to have mosquito larvae. The larvae were collected with a Pasteur pipette and the material stored in plastic tubes.

The collected mosquitoes were transported to the Regional Entomology Laboratory in Dourados, Mato Grosso do Sul, and sent to Faculdade de Saúde Pública da Universidade de São Paulo to the identification and confirmation of the specimens, then later returned to the Regional Entomology Laboratory in Dourados. Due to the inadequate conditions of transportation, transfer and storage of the collected specimens, only the male specimen was in a suitable state of preservation for deposit in Coleção Entomológica de Referência do Departamento de Epidemiologia da Universidade de São Paulo (FSPUSP). The identification was made using the taxonomic keys of Consôli and Lourenço-de-Oliveira (1994) and Forattini (2002).

\section{Results}

\section{Aedes (Ochlerotatus) lepidus (Cerqueira \& Paraense, 1945)}

New records. BRAZIL - Mato Grosso do Sul • Alcinópolis; Templo dos Pilares Municipal Park; $18^{\circ} 19^{\prime} 26^{\prime \prime} \mathrm{N}$, 05342'21"S (Fig. 1) 443 m elev.; 16 Nov. 2015; Paulo Silva Almeida and Andreia Fernandes Brilhante leg.; in a stone hole; four larvae, and with CDC traps; 11 adults $(1 \widehat{\jmath}, 10$ ㅇ), $1 \lesssim$ deposited in FSP-USP (E-15919).

Morphological characterization. Female (Fig. 2A, B): head with dark maxillary palpus, except at the apex of palpomer 5, presenting a group of pale scales. Thorax with integument brown dark; scutum and scutellum coated with patches of pale scales; mesokatepisternum with scales on the prealar button; hind femur and tibia with a ring of pale scales at the apex; tarsi dark-scaled; tarsi fore- and midungues usually toothed and hindungues. Wing dark-scaled. Abdomen with at least some terga presenting basal bands of pale scales. Narrow and retractable abdominal segment VIII, not visible on external examination, long and narrow cerci.

Male (Fig. 3): head with palpi two-thirds of the length of the proboscis, the last two articles of equal length, slightly bristly, with a narrow basal pale band on the last three segments. Antenna just over half the length of proboscis, very feathery. Thorax as in females. Genitalia, gonocoxite absent the apical dorsomesal lobe, with the basal dorsomesal lobe present and endowed with a tuft of thick and thin bristles, one more developed and stronger than the others; claspette spiculous columnar and with apical filament substantially shorter than the stem, and with single and long retrodirected process that gives the arrowhead a contour set. Aedeagus without apical or lateral teeth.

Larvae (Fig. 2 C): head: (dorsal view) 5-7-C setae, or at least 7-C varying between doubles, triples and multiples. Abdominal segment VIII: pecten arranged in a single row and regularly spaced from each other, the scales of pecten have chitinized teeth, bilateral, enlarged from the base to the apex. Siphon: Seta 1-S is multiple and inserted beyond siphonal pecten. Segment X has incomplete saddle. 

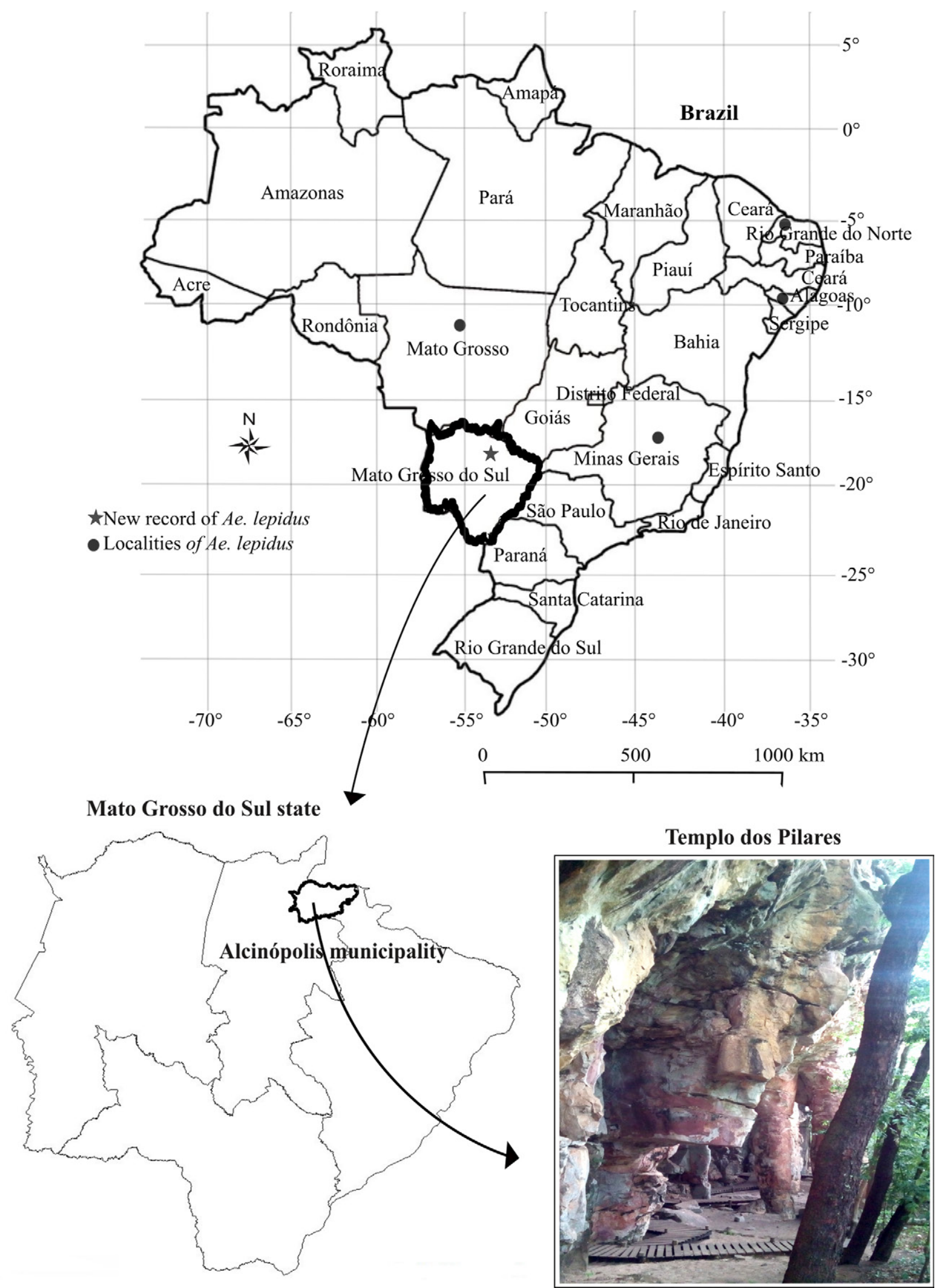

Figure 1. Geographical distribution of Aedes (Ochlerotatus) lepidus in Brazil. Entrance of Templo dos Pilares, Alcinópolis, Mato Grosso do Sul state, Brazil. Photo: Templo dos Pilares by Andreia Fernandes Brilhante. 

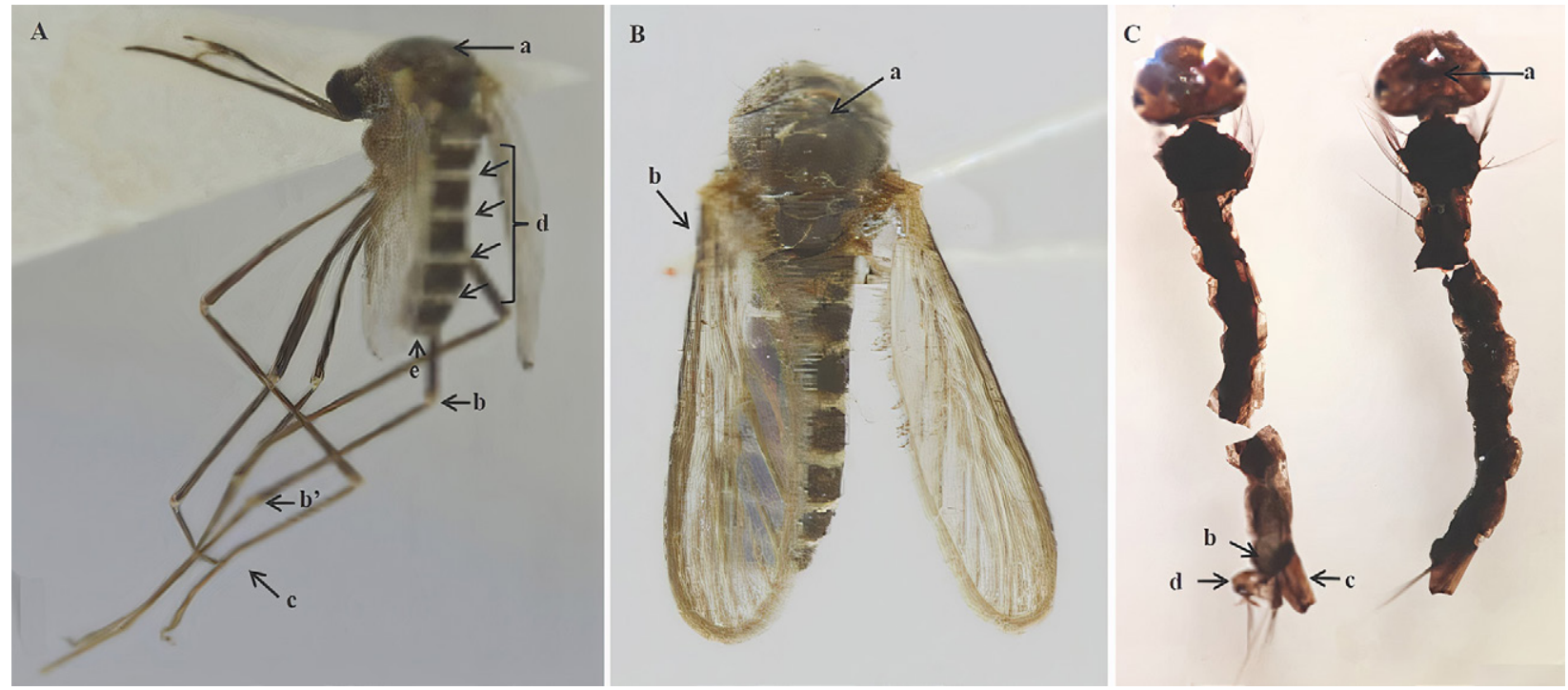

Figure 2. Aedes (Ochlerotatus) lepidus. A, B. Female: (A) lateral view: (a) thorax: integument brown dark; (b) hind femurs (b') hind tibia with a ring of pale scales at the apex; (c) tarsi dark-scaled; (d) abdomen: abdominal terga usually with basal pale bands; (e) narrow and retractable abdominal segment VIII, not visible on external examination; (B) dorsal view: thorax: (a) scutum covered with patches of pale scales; (b) wing dark-scaled. C. Larva: (a) head (dorsal view): 5-7-C setae, or at least 7-C varying between doubles, triples and multiples; (b) abdominal segment VIII: pecten arranged in a single row and regularly spaced from each other, the scales of pecten have chitinized teeth, bilateral, enlarged from the base to the apex; (c) siphon: seta 1-S multiple and inserted beyond siphonal pecten; (d) segment $\mathrm{X}$ with incomplete saddle.
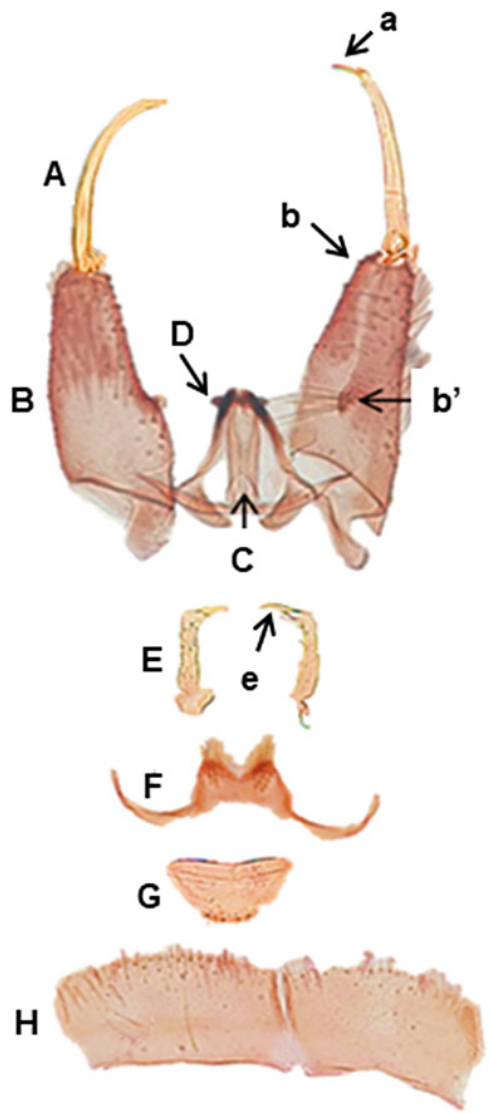

Figure 3. Male genitalia of Aedes lepidus. A. Gonostylus simple: (a) apical gonostylar claw. B. Gonocoxite: (b) absent apical dorsomesal lobe, (b') basal dorsomesal lobe present and endowed with a tuft of thick and thin bristles. C. Aedeagus without apical or lateral teeth. D. Paraproct. E. Claspette: spiculous columnar: (e) apical filament substantially shorter than the stem, with a single and long process retrodirected like an arrowhead. F. Tergal lobe IX. G. Sternum IX. H. Abdominal segment VIII.

\section{Discussion}

Aedes lepidus is similar to Aedes (Ochlerotatus) jacobinae (Serafim \& Davis, 1933); however, their females differ; Ae. lepidus have pale scales on the apex of the last article of the palp, distinct white scale patches on the scutum, and white rings at the apexes of femurs and tibiae, all of which are absent in Ae. jacobinae. In the male genitalia of Ae. jacobinae, the claspette has an angular retrodirected process that results in a triangular outline, which is different from that of Ae. lepidus. Cerqueira and Paraense (1945) described Ae. lepidus based on adult insects from Belo Horizonte, Minas Gerais (the type locality) and Santana do Ipanema, Alagoas (an additional locality). The immature forms, larvae and pupae were described by Cerqueira (1957).

The subgenus Ochlerotatus Reinert, 2000 comprises species that grow on the soil in natural or artificial containers with or without vegetation that accumulate rainwater, both in wild and urban locations (Forattini 1965, 2002). These species can be temporarily found in rock excavations, land depressions, puddles, drainage ditches, and brackish ponds (Harbach 2021b). Aedes lepidus has been reported from artificial containers around homes and associated with Ae. aegypti (Cerqueira 1957) and Culex (Culex) quinquefasciatus Say, 1823 (Consoli and Oliveira 1994). It is a zoophilic (ornithophilous) mosquito that, in due course, can feed on humans (Consoli and Oliveira 1994). Under laboratory conditions, Ae. lepidus presented vector competence to transmit Plasmodium gallinaceum and was used as an experimental model of malaria (Paraense 1945). In an entomological survey carried out in Rio Grande do Norte, Inacio (2016) 
verified the anthropophilic behavior and crepuscular activity of Ae. lepidus collected in Shannon traps.

Our new record of Ae. lepidus from Mato Grosso do Sul expands the known geographical distribution of the species, which which has previously been known from the states of Alagoas, Mato Grosso, Minas Gerais, and Rio Grande do Norte (Paraense, 1945; Cerqueira 1957; Xavier et al. 1980; Inacio 2016; Andrade et al. 2020; Fig. 1).

New records that extend the geographic ranges of insect species are important information for research on the potential risk of human populations exposed to infectious agents, such as in rocky areas like Templo dos Pilares Municipal Park, which is much visited by researchers and tourists. However, Ae. lepidus apparently has no epidemiological importance.

With this new record, the number of culicid species in Mato Grosso do Sul is now 63.

\section{Acknowledgements}

We thank the Universidade Federal da Grande Dourados for the English review. The authors also thank the reviewers and editors, Dr. Fabio Laurindo da Silva and Robert Forsyth, for their contributions to this paper.

\section{Authors' Contributions}

All authors contributed to the study conception and design. Data collection was performed by PSA, JOS, TMS, PCCF, CJSC, MTO and AFB; identification was conducted by PSA and MBP. The first draft of the manuscript was written by PSA and AFB. The review of the manuscript was written by AFB, HCNA and MBP. The map was designed by HCNA. All authors commented on previous versions of the manuscript. All authors read and approved the final manuscript.

\section{References}

Aguiar RS, Landa BS, Goettert JD (2016) Reflexões sobre as relações entre a arte rupestre de Alcinópolis, o contexto regional de pinturas e gravuras e a mobilidade de povos caçadores e coletores em Mato Grosso do Sul. Nanduty 4: 1-10.

Almeida PS, Paula MB, Brilhante AF, Medeiros-Sousa AR, NeitzkeAbreu HC, Carrijo CJS, Costa Filho PCD, Galati EAB (2019) Phlebotomine (Diptera: Psychodidae) fauna in a cavern containing cave paintings and its surrounding environment, Central-West Brazil. Acta Tropica 199: 105151.
Andrade DC, Morais SA, Marteis LS, Gama RA, Freire RCM, Rekowski BS, Ueno HM, La Corte R (2020) Diversity of Mosquitoes (Diptera: Culicidae) in the Caatinga biome, Brazil, from the widespread to the endemic. Insects 11: 468. https://doi.org/ 10.3390/insects11080468

Cerqueira NL (1957) Descrição da larva e pupa de Aedes (Ochlerotatus) lepidus Cerqueira \& Paraense (Diptera: Culicidae, Culicini). Boletim do Museu Paraense Emilio Goeldi, Zoologia 3: 1-6.

Cerqueira NL, Paraense WL (1945) Uma nova espécie de Aedes, transmissora de Plasmodium gallinaceum (Diptera Culicidae). Memórias do Instituto Oswaldo Cruz 42: 11-15. https://doi.org/ 10.1590/S0074-02761945000100002

Consoli RAGB, Oliveira RL (1994) Principais mosquitos de importância sanitária no Brasil. Editora FIOCRUZ, Rio de Janeiro, Brazil, 228 pp.

Forattini OP (1965) Entomologia médica. Editora Universidade de São Paulo, São Paulo, Brazil, 506 pp.

Forattini OP (2002) Culicidologia médica. Editora EDUSP, São Paulo, Brazil, 864 pp.

Gaffigan TV, Wilkerson RC, Pecor JE, Stoffer JA, Anderson T (2015) Systematic catalog of Culicidae. http://mosquitocatalog.org/intro. aspx. Accessed on: 2019-8-8.

Harbach RE (2021a) Mosquito taxonomic inventory. http://mosquitotaxonomic-inventory.info/simpletaxonomy/term/6065. Accessed on: 2021-5-3.

Harbach RE (2021b) Mosquito taxonomic inventory. http://mosquitotaxonomic-inventory.info/simpletaxonomy/term/6129. Accessed on: 2021-5-3.

Hutchings RW, Sallum MAM, Hutchings RSG (2020) Culicidae in catálogo taxonômico da fauna do Brasil. PNUD. http://fauna.jbrj. gov.br/fauna/faunadobrasil/77138 Accessed on: 2020-10-4.

Inacio CLS (2016) Mosquitos (Diptera, Culicidae) em área de caatinga degradada na região Seridó, Estado do Rio Grande do Norte, Brasil. MSc thesis, Universidade Federal do Rio Grande do Norte, Centro de Biociências, Rio Grande do Norte, Brazil, 125 pp.

Martins VP, Silveira DA, Ramalho IL, Florindo MI (2013) Aedes albopictus no Brasil: aspectos ecológicos e riscos de transmissão da dengue. Entomotropica 28: 75-86.

Paraense WL (1945) A transmissão de Plasmodium gallinaceum pelo Aedes (Ochlerotatus) lepidus. Memórias do Instituto Oswaldo Cruz 42: 81-84. https://doi.org/10.1590/S0074-02761945000100008

Prefeitura de Alcinópolis (2019) Parque Natural Municipal Templo dos Pilares. http://www.alcinopolis.ms.gov.br/turismo/2-parquenatural-municipal-templo-dos-pilares.html. Accessed on: 20198-8.

Xavier, S. H., S. S. Mattos, E. Cerqueira, and P. V. Calabria. 1980. Geographical distribution of Culicidae in Brazil-VI. State of Rio Grande do Norte (Diptera, Culicidae). Mosquito Systematics 12: $356-366$.

Wilkerson RC, Linton YM, Fonseca DM, Schultz TR, Price DC, Strickman DA (2015) Making mosquito taxonomy useful: A stable classification of Tribe Aedini that balances utility with current knowledge of evolutionary relationships. PloS ONE 10: e0133602. https://doi.org/10.1371/journal.pone.0133602 